\title{
Clinicopathological features of untreated fibrous hamartoma of infancy
}

\author{
S E E Efem, M D Ekpo
}

\begin{abstract}
Aim-To study the clincopathological features of fibrous hamartoma of infancy in Nigerian children.

Methods-Six children aged between 6 months and 10 years were studied. All specimens were stained with haemotoxylin and eosin and examined routinely. The children were followed up for between one and three years.

Results-In four of the children lesions were present at birth; in the other two they appeared by the age of 1 year. Some of the children had had the lesion for between three and 10 years. All lesions were located in the subcutis. They were solitary and varied in size and shape. They had grown rapidly up to the age of 5, after which growth decelerated, but did not stop or regress. The younger the child the less clearly demarcated was the tumour on the deep surface. In the older children the capsule was more developed.

Conclusions-Fibrous hamartoma of infancy is rare, but it is important for clinicians to know that it is benign and readily amenable to treatment.
\end{abstract}

(F Clin Pathol 1993;46:522-524)

Fibrous hamartoma of infancy is a rare tumour-like malformation that is remarkably uniform in histological appearance. ${ }^{12}$ It appears within the first two years of $\operatorname{life}^{23}$ and is usually solitary. The usual sites are the axilla, shoulders and upper arm, but various other anatomical locations have also been reported. The lesion is located in the subcutaneous tissue or reticular dermis. The diameter ranges from $1-8 \mathrm{~cm}$. There is usually poor demarcation from the adjacent soft tissues $^{1-3}$; less often, circumscription is present and the tumour is encapsulated. ${ }^{3}$

The patients studied afforded the opportunity not only to highlight the clinicopathological features of this condition in Nigeria but also to study its natural course.

\section{Methods}

Six patients with fibrous hamartoma of infancy seen at the University of Calabar Teaching Hospital over eight years) (1983-1990) were studied. Information relating to clinical features such as age, sex, duration of swelling, site, shape, size and consistency were documented, as were findings at surgery. All specimens were subject to routine histopathological examination and haematoxylin and eosin stained sections of each tumour were reviewed.

On discharge from hospital, patients were followed up for periods of one to three years.

\section{Results}

The six patients with fibrous hamartoma of infancy had an age range from 6 months to 10 years. There were five females and one male. In four patients the lesions had been present at birth or appeared shortly afterwards. In two cases the neoplasms appeared after 1 year of age. All lesions were located in the subcutis. They were solitary and varied in size and shape (table). The lesions were found in the axilla (two cases) (fig 1), in the supraclavicular fossa (two cases), over the left scapula (one case) (fig 2), and over the femoral triangle (one case). They grew rapidly from the outset up to the age of about 5 years. Growth then slowed down, but did not stop or regress. Vital structures such as nerves and blood vessels in the vicinity were neither infiltrated nor compressed. None of the lesions was painful, warm, or tender. There were no constitutional disturbances or local pressure symptoms despite the enormous size attained by some tumours.

At surgery the axillary lesions that had been present for only six and nine months, respectively, had thin capsules which were ill defined on their deep surfaces. By contrast, those lesions that had been present for three years to 10 years had well developed capsules (fig 3), the oldest lesion developing
University

Department of

Surgery, University

Teaching Hospital,

Calabar Cross River

State, Nigeria

S E E Efem

M D Ekpo

Department of

Morbid Anatomy

M D Ekpo

Correspondence to:

S E E Efem

Accepted for publication

17 December 1992
Features of fibrous hamartoma of infancy in Nigerian children

\begin{tabular}{|c|c|c|c|c|c|c|c|}
\hline Age & Sex & Duration & Site & Shape & Size $(\mathrm{cm})$ & Capsule & Initial diagnosis \\
\hline $\begin{array}{l}6 \text { months } \\
9 \text { months } \\
2 \text { years }\end{array}$ & $\begin{array}{l}\text { Male } \\
\text { Female } \\
\text { Female }\end{array}$ & $\begin{array}{l}6 \text { months } \\
9 \text { months } \\
1 \text { year }\end{array}$ & $\begin{array}{l}\text { Right axilla } \\
\text { Right axilla } \\
\text { Left supracla- } \\
\text { vicular fossa }\end{array}$ & $\begin{array}{l}\text { Spherical } \\
\text { Ovoid } \\
\text { Ovoid }\end{array}$ & $\begin{array}{l}20 \text { diameter } \\
6 \text { diameter } \\
6 \times 5 \times 4\end{array}$ & $\begin{array}{l}\text { Diffuse } \\
\text { Diffuse } \\
\text { Thin but } \\
\text { well defined }\end{array}$ & $\begin{array}{l}\text { Cystic hygroma } \\
\text { Cystic hygroma } \\
\text { Lymphadenopathy }\end{array}$ \\
\hline 3 years & Female & 3 years & $\begin{array}{l}\text { Right femoral } \\
\text { triangle }\end{array}$ & Ovoid & $5 \times 4 \times 3$ & $\begin{array}{l}\text { Ill defined on the } \\
\text { deep surface }\end{array}$ & Aneurysm \\
\hline 7 years & Female & 6 years & $\begin{array}{l}\text { Over the left } \\
\text { scapula }\end{array}$ & $\begin{array}{l}\text { Cucumber- } \\
\text { shaped }\end{array}$ & $20 \times 10 \times 10$ & Thin, well defined & Soft tissue tumour \\
\hline 10 years & Female & 10 years & $\begin{array}{l}\text { Left supracla- } \\
\text { vicular fossa }\end{array}$ & $\begin{array}{l}\text { Kidney } \\
\text { shaped }\end{array}$ & $5 \times 4 \times 4$ & $\begin{array}{l}\text { Well defined } \\
\text { lobulated with two } \\
\text { septa }\end{array}$ & Lymphadenopathy \\
\hline
\end{tabular}




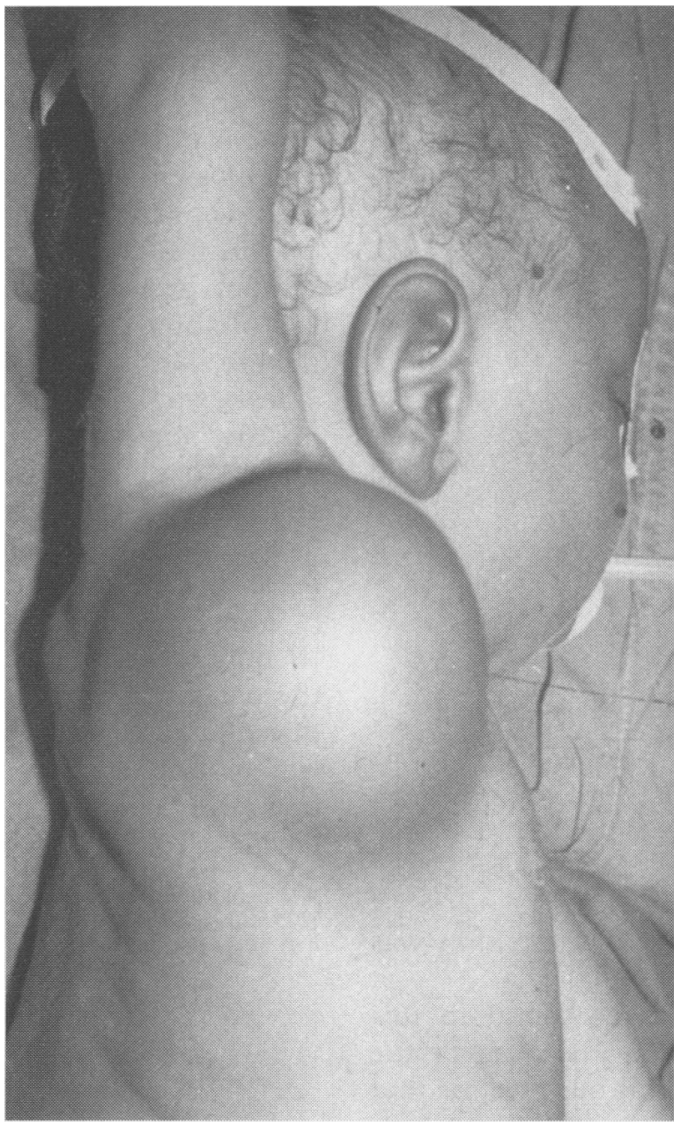

Figure 1 Fibrous hamartoma of infancy occurring in the right axilla of a six month old Nigerian boy.

septa that penetrated the lesion. The older lesions were easier to excise.

Macroscopically, the tumours were firm and rubbery; the cut surfaces were greyishwhite in colour and showed definite capsular demarcation in some and pseudocapsule formation in others.

Microscopically, the tumours showed the usual complex histology consisting of (i) areas of mature adipose tissue interposed between fibrous bands; (ii) foci of primitive mes-

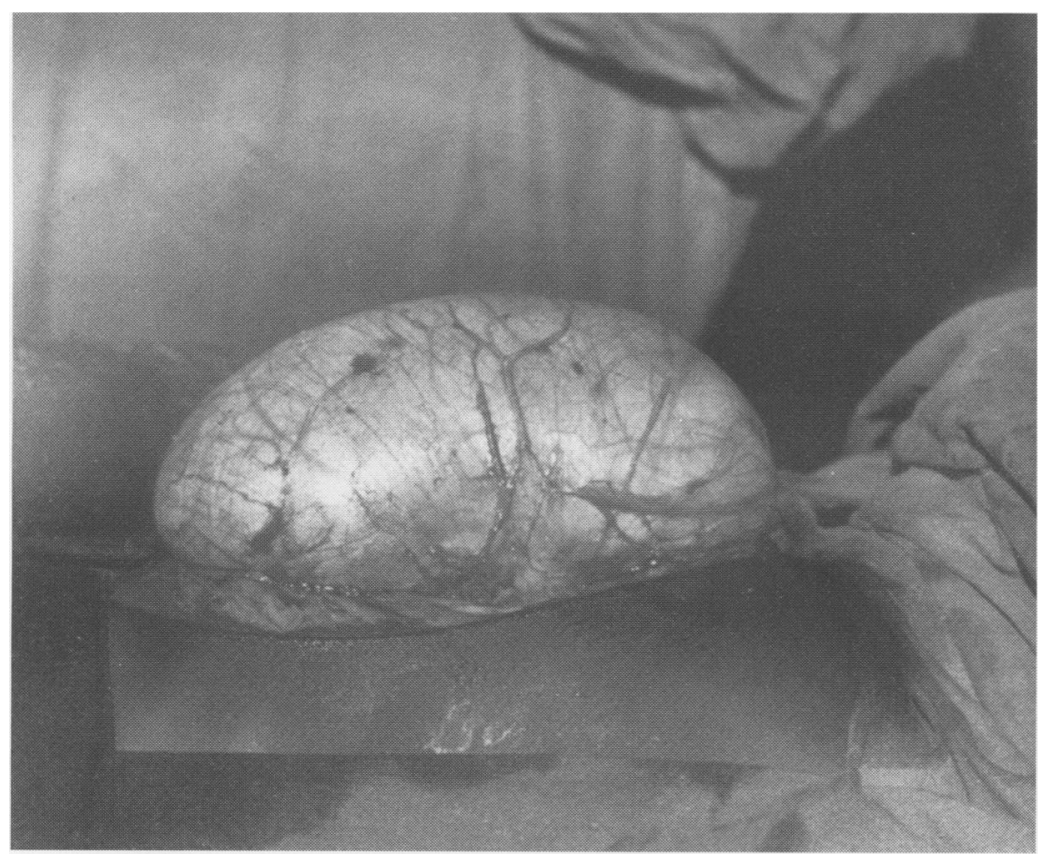

Figure 3 Same tumour as in figure 2, viewed at surgery to show well developed capsule.

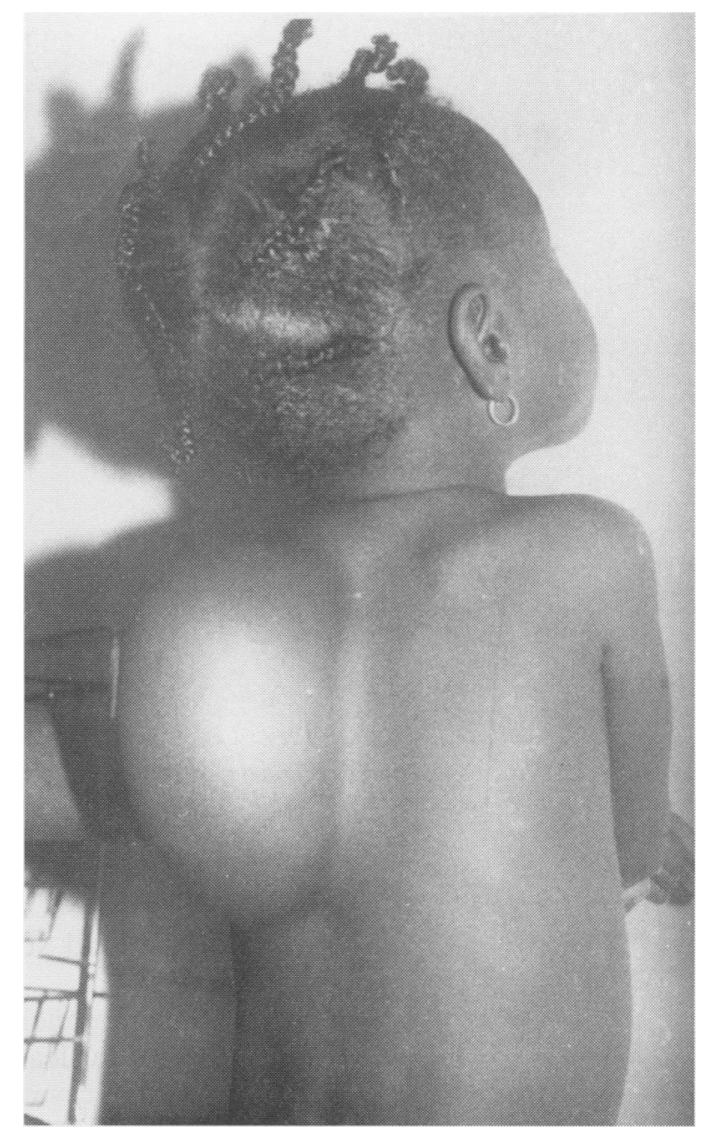

Figure 2 Fibrous hamartoma of infancy over the left scapula of a 7 year old Nigerian girl.

enchyme-like tissue; and (iii) masses of spindle cells some of which formed whorls (fig 4). Mitotic figures and cellular anaplasia were not found.

The lesions were variously misdiagnosed clinically as cervical lymphadenopathy, axillary cystic hygroma, and "soft tissue tumour" of back. There was no loss of function following surgical excision and the tumour did not recur in any of the patients.

\section{Discussion}

Much of our knowledge of these tumours stems from cases with early presentation and prompt surgical intervention. Fibrous hamartoma of infancy is a rare entity that is hardly mentioned in textbooks of general surgery and pathology. It is important for clinicians to know about its benign nature and amenability to treatment to avoid unnecessary anxiety, start appropriate treatment, and determine the likely outcome.

The late presentation of some of the patients in this series provided the opportunity to show the clinical and pathological features of the tumour at a later stage of evolution. Tumours resected from patients aged 6 months to 3 years had gross features that corresponded with the usual description of the lesion, including a poorly defined capsule. ${ }^{1-3}$ In those patients who presented later and had their lesions for a longer time, the tumour capsule was more complete and well formed. In such cases the cleavage planes were more defined, except at the point of 


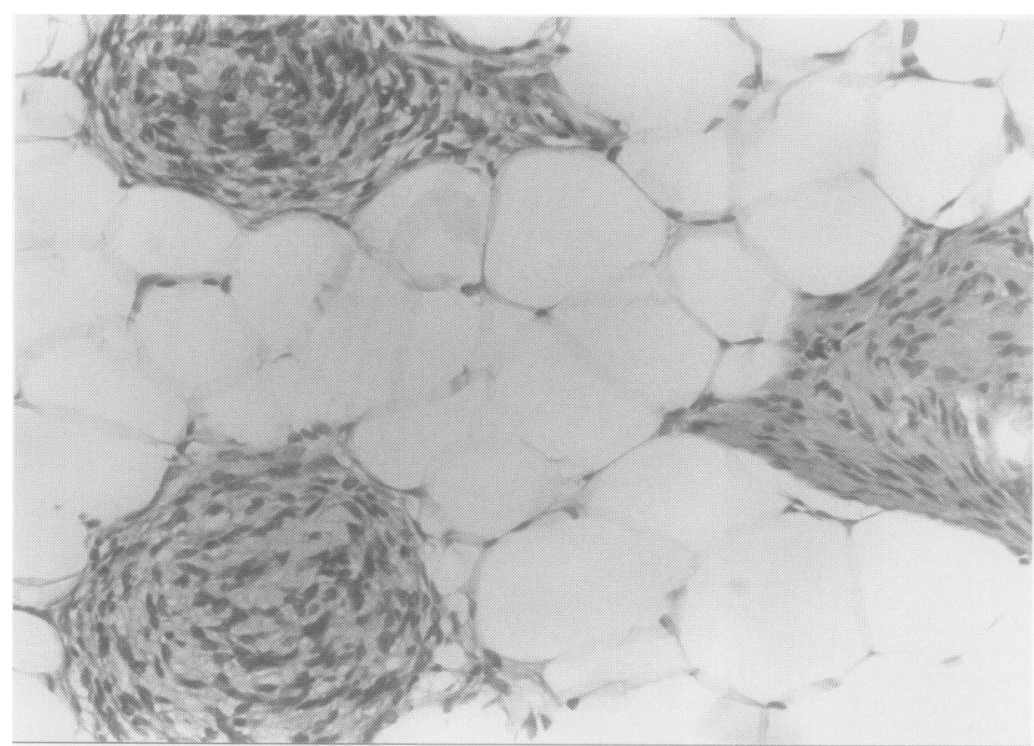

Figure 4 Microscopy of fibrous hamartoma of infancy showing the usual pattern of mature adipose tissue, spindle cells, and primitive mesenchymal tissue (haemotoxylin and eosin). axilla is firm and rubbery rather than spongy and is much easier to excise than cystic hygroma. Despite the late presentation of some of the patients, there was no associated neurological or other physical disability either before or after surgery.

The findings of this study show that the tumour grows rapidly from birth up to the age of about 5 years; it then slows down but growth does not stop, nor is there regression. There was no major departure from the microscopic pattern usually described except for a better formed capsule. Malignant change was not observed. The neurofibromalike pattern described by Enzinger ${ }^{1}$ as a late feature of the tumour was not seen.

Thus fibrous hamartoma of infancy seems to undergo definitive changes the older the the patient. The lesion probably continues to develop as the child grows. Delayed surgery was not associated with increased risk of operative complication: in fact it seemed to facilitate complete resection of the tumour.

We are grateful to Dr S Variend, The Children's Hospital, Sheffield, for his help in drafting this report and in preparation of the photomicrograph.

entry of the blood supply, and excision was much easier.

The female preponderance found in this study may be misleading on account of the small number of cases, but it may well be that the disease is more common in African girls than boys. This not the case in caucasians. ${ }^{14}$

Clinically the axillary lesions resembled cystic hygroma and in some instances were diagnosed as such. Fibrous hamartoma of the
1 Enzinger FM. Fibrous hamartoma of infancy. Cancer 1965;18:241-8.

Paller AS, Gonzalez-Crussi F, Sherman JO. Fibrous hamartoma of infancy. Eight additional cases and a review of the literature. Arch Dermatol 1989;125:88-91. Lee JT, Girvan EP, Armstrong RF. Fibrous hamartoma of infancy. $\mathcal{F}$ Pediatr Surg 1988;23:759-61.

4 Chung FM. Pitfalls in diagnosing benign soft tissue tumours in infancy and childhood. Pathol Annu 1985;20:323-96. 